\title{
Utilising a cultural-historical analysis to map the historicity of Social Studies, Natural Science and Technology education in the early years
}

\begin{tabular}{|c|c|}
\hline \multicolumn{2}{|c|}{$\begin{array}{l}\text { Authors: } \\
\text { Hannelie du Preez }{ }^{1} \text { (D) } \\
\text { Retha van Niekerk }{ }^{2} \text { (D) }\end{array}$} \\
\hline \multicolumn{2}{|c|}{$\begin{array}{l}\text { Affiliations: } \\
{ }^{1} \text { Department of Early } \\
\text { Childhood Development } \\
\text { and Education, University } \\
\text { of Pretoria, South Africa }\end{array}$} \\
\hline \multicolumn{2}{|c|}{$\begin{array}{l}{ }^{2} \text { Department of Early } \\
\text { Childhood Education, } \\
\text { North-West University, } \\
\text { South Africa }\end{array}$} \\
\hline \multicolumn{2}{|c|}{$\begin{array}{l}\text { Corresponding author: } \\
\text { Hannelie du Preez, } \\
\text { hannelie.dupreez@up.ac.za }\end{array}$} \\
\hline \multicolumn{2}{|c|}{$\begin{array}{l}\text { Dates: } \\
\text { Received: } 15 \text { Aug. } 2017 \\
\text { Accepted: } 03 \text { Aug. } 2018 \\
\text { Published: } 29 \text { Nov. } 2018\end{array}$} \\
\hline \multicolumn{2}{|c|}{$\begin{array}{l}\text { How to cite this article: } \\
\text { Du Preez, H. \& van Niekerk, } \\
\text { R., 2018, 'Utilising a } \\
\text { cultural-historical analysis to } \\
\text { map the historicity of Social } \\
\text { Studies, Natural Science and } \\
\text { Technology education in the } \\
\text { early years', South African } \\
\text { Journal of Childhood } \\
\text { Education } 8(2) \text {, a573. } \\
\text { https://doi.org/10.4102/ } \\
\text { sajce.v8i2.573 }\end{array}$} \\
\hline \multicolumn{2}{|c|}{$\begin{array}{l}\text { Copyright: } \\
\text { (C) 2018. The Authors } \\
\text { Licensee: AOSIS. This } \\
\text { is licensed under the } \\
\text { Creative Commons } \\
\text { Attribution License. }\end{array}$} \\
\hline \multicolumn{2}{|l|}{ Read online: } \\
\hline 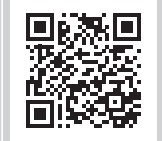 & $\begin{array}{l}\text { Scan this QR } \\
\text { code with your } \\
\text { smart phone or } \\
\text { mobile device } \\
\text { to read online. }\end{array}$ \\
\hline
\end{tabular}

Background: South Africa needs citizens who are morally sound, adaptive to change, technologically innovative and literate in socio-scientific issues. The young child is apparently being prepared for active citizenry through basic "Social Science, Natural Sciences and Technology" education as encapsulated in the South African curriculum.

Aim: We foreground a theoretical and analytical framework to map the cultural-historical trajectory of South Africa's Beginning Knowledge curriculum.

Setting: Cultivating citizenship requires that these science subject domains be incorporated in a coherent, well-conceptualised and relevant early childhood curriculum as suggested by international literature. Educators need to be specialists in socio-scientific issues in both the content and pedagogy of these sciences in order to expound the curriculum.

Methods: Our newly coined hybridised theoretical framework - the 'Hybrid CHAT' - together with an aligned analytical framework enabled us to illuminate the historical subject-didactical genetic development of Beginning Knowledge. An extensive sample of typographical textbooks, artefacts and cultural tools were analysed and interpreted.

Results: Beginning Knowledge is afforded limited teaching time. The knowledge, skills and values associated with these science subjects serve to support and strengthen the acquisition of language and mathematics competencies. Currently, Beginning Knowledge does not sufficiently prepare child citizens for the global demands of the 21st century.

Conclusion: Hybrid CHAT could invite further studies to place Beginning Knowledge on par with international curricula. This would also align the curriculum with the aspirations for an ideal South African citizenry as well as prepare child citizens to pursue Science and Technology for social development.

\section{Introduction}

Socio-scientific issues (SSI) are defined as cognisant of multifaceted and open-ended social issues that are contextually, conceptually and methodologically linked with science (Ratcliffe \& Grace 2003; Roberts 2007, 2011; Sadler 2011; Sadler, Barab \& Scott 2006; Zeidler \& Kahn 2014). Scholars of SSI propose that this particular evidence-based knowledge system cultivates scientifically literate citizens, as the nature of science (NOS) is rooted in everyday scientific issues that require collective social integrity, moral sensitivity and environmental awareness (Ratcliffe \& Grace 2003; Roberts 2007, 2011; Sadler 2011; Sadler, Barab \& Scott 2006; Zeidler \& Kahn 2014). An SSI knowledge system, furthermore, promotes socio-scientific thinking and reasoning that are akin to scientific habits of mind, which includes involvedness, negotiation, multiple perspectives, inquiry and scepticism (Sadler 2011; Sadler et al. 2006; Zeidler \& Kahn 2014). A general understanding of a science knowledge system, according to Abd-El-Khalick, Bell and Lederman (1998) and Hodson (2009), is the systematic acquisition and utilisation of knowledge and didactics that include transdisciplinary areas, such as Sociology, Philosophy, the History of Science and, conclusively, Beginning Knowledge (BK).

It is not beyond the ability of the young child to come to think, reason and converse in a sophisticated manner about what it means to be human in this world and to ascribe meaning to the self, others and their environment. Coming to appreciate and meeting young children where they are in this present moment is to realise that they are already active and contributing child citizens. It is posited that SSI knowledge systems incite young children to integrate diverse science knowledge systems in order to help discover their environment and, in turn, promote their active 
participation as functioning child citizens, which either compromises or advances their relationships with others and the world. We are also convinced that the integration of SSI can ultimately deepen and transform the young child's understanding and experience about who he or she is in relation to others within the environment. Inculcating SSI knowledge systems in the young child's school curriculum should commence in the early years.

SSI knowledge systems have received much attention from international studies during the past two decades, and more studies are destined to follow. Socio-scientific issues knowledge systems are inevitably an issue of demand, as future vocations will draw on multi- and transdisciplinary knowledge systems and demand that individuals creatively transfer knowledge and skills across knowledge disciplines (Du Preez 2016; Kaku 1997, 2011). Scholars have started preparing the groundwork for conceiving a well-conceptualised and intended SSI knowledge system, which not only delineates the nature of the science subject content but also advocates the most suitable early childhood pedagogical approaches.

The following scholars have inspired the auspicious transdisciplinary studies that have contributed to the SSI knowledge system for the young child. Firstly, the importance of teaching scientific literacy, SSI, NOS and technology to promote citizenship for the 21st century is justified in the works of Bybee (2010), Erduran and Dagher (2015), Ratcliffe and Grace (2003) and Roberts (2011). Secondly, the teaching of Science and Technology in the early years, using socialculturalism, constructivism and play as pedagogy, is supported by Chaillé and Britain (2003), Eshach (2006), Fleer and Pramling (2015), Holzman (2009), Settlage and Southerland (2012) and Siu and Lam (2005). Thirdly, Maxim (2014), Parker (2009) and Seefeldt, Castle and Falconer (2014) have elaborated extensively on teaching and learning Social Studies in the early years in order to promote citizenship. Lastly, we have also utilised international frameworks dedicated to providing curriculum developers with guidelines for teaching, learning and assessing the respective subjects called 'Social Studies', 'Science' and 'Technology', from kindergarten, preschool or Grade $\mathrm{R}$ to Grade 12. These respective initiatives are the Creative Little Scientists (Glauert \& Manches 2012), the National Research Council (NRC 2011), the Next Generation Science Standards (NGSS 2013) and the Nuffield Foundation and the Association for Science Education (NFAS 1998). Pertaining to Social Studies and Technology education, the frameworks of the National Council for Social Studies (NCSS 2010) and the International Society for Technology in Education (ISTE 2008) have provided insight into the nature of these knowledge systems. Lastly, the interdisciplinary Science, Technology, Engineering and Mathematics (STEM) and Science, Technology, Engineering, Arts and Mathematics (STEAM) education frameworks and the National Association for the Education of the Young and National Association of Early Childhood Specialists in State Departments of Education (NAEYC \& NAECS/SDE 2002) have contributed significantly to various studies and the development of curricula.
In light of the previous paragraph, most scholars agree that intentionally teaching Social Studies, Science and Technology in the early years contributes to acquiring an SSI knowledge system for citizenship. However, what is still undecided is exactly how to achieve this objective. Our contention is that, because the South African BK study area is not well grounded, we need to explore its nature and trajectory across culturalhistorical realms. We aim to answer the following research question: How can cultural-historical research, as theoretical and analytical framework, contribute to interpreting the genetic development of BK education in South Africa?

To attain this goal we will point out three crucial aspects in this article. Firstly, we will delineate the nature of BK as a knowledge system. Secondly, we will extrapolate on our newly developed theoretical framework, coined the 'Hybrid CHAT'. This theoretical framework has guided us in identifying three key contributors (or prongs) to the culturalhistorical development of this knowledge system. Thirdly, we will propose how our theoretical framework aligns with the analytical framework in order to construct, analyse and interpret the BK knowledge system.

We will finally propose that more scientific investigations are needed to firstly restore the teaching-learning trajectory of BK; secondly to strengthen and enrich the development of SSI knowledge systems in the early years. By elevating BK from being a mere theoretical infused domain to a practice in the classroom can equip child citizens to apply themselves and solve problems in everyday life and in the 21st century.

\section{Review of the body of scholarship Nature of Science}

The intentional inculcation of Social Studies, Science and Technology can strengthen democratic citizenry. It also equip active child citizens with scientific reasoning skills for informed decision-making on numerous SSI issues. Thus, NOS is imperative to the understanding of science in its sociocultural context (Erduran \& Dagher 2015). To describe the nature of knowledge systems one should be mindful of the unique characteristics and suppositions of this knowledge system, based on how it has developed socially, philosophically, historically and scientifically (Abd-El-Khalick et al. 1998; Hodson 2009). Nature of science is best defined by looking at three different aspects, namely (1) preserving the historicity of knowledge systems, (2) promoting citizenship through knowledge systems and (3) the curriculum as a collective knowledge system.

\section{Preserving the historicity of knowledge systems}

Individuals are not born with knowledge about the past; they intentionally have to develop cognisance of and appreciation for the meaning of historical knowledge systems (Le Roux 2013; Marwick 2001; Nutbrown \& Clough 2014). Actively engaging with historical knowledge systems not only stimulates one's thinking, emotions and understanding 
but also enables one to reconnect knowledge systems (Le Roux 2013; Marwick 2001; Nutbrown \& Clough 2014). Connected knowledge systems help reconstruct or elaborate on existing knowledge systems in order to contribute, share, transform and reach consensus on current thinking (Rückriem 2003; Sannino, Daniels \& Gutiérrez 2009). By preserving knowledge systems, a historical consciousness within society is sustained. Saving past voices from being forgotten and generating a full, trustworthy and accurate record of a knowledge system are beneficial to current and future generations (Booyse et al. 2013). Thus, any discontinuity or disconnectedness between past and present knowledge systems can have far-reaching consequences.

Standing at the beginning of the 21st century, astonishingly, few inquiries have been made to map the historicity of South African curricula or the intended science knowledge system for school learners (Pinar 2010; Soudien 2010). We confirm that BK for the young child has not been intellectually mapped or scrutinised - neither in the apartheid Environmental Education syllabus (Departement van Onderwys [DvO] 1991; Du Raan 1978; Lea \& Gildenhuys 1967a, 1967b) nor in the post-apartheid Life Skills curricula (Department of Education [DoE] 2002, 2003, 2011) could we locate a historiography for early childhood curricula implemented. A disconnected knowledge system not only impoverishes the national education system and teacher preparation programmes from benefiting from international discoveries but also deprives societies of cultivating a particularly envisioned citizen and inhibits individuals to advance with the demands of the 21st century (Asabere-Ameyaw, Sefa Dei \& Raheem 2012; Booyse et al. 2013; Horsthemke et al. 2013).

\section{Promoting citizenship through knowledge systems}

An SSI knowledge system resonates with the core of human existence - our yearning for interconnectedness and ultimately deepens our relationship with society and a supreme source in the metaphysical realms (Asabere-Ameyaw et al. 2012). Knowledge systems are inherently and genetically disposed to all societies and are, therefore, not a sole product of a society or country, as one may sometimes be led to believe (Asabere-Ameyaw et al. 2012; Le Roux 2013). Therefore, the transference and progression of knowledge systems promote understanding and a sense of belonging in the child citizen, as well as interconnectivity among the child citizen, society and his or her environment. The subjects Social Studies, Science and Technology are socially and culturally inspired knowledge systems (Abd-El-Khalick et al. 1998; Hodson 2009), and these knowledge systems contribute to human development on an interpersonal, civic, moral and cognitive level (Booyse et al. 2013). Science knowledge systems, therefore, prepare child citizens for the demands of the 21st century.

In relation to what kind of citizen is being envisioned for South Africa, the Curriculum and Assessment Policy Statement (CAPS) (DoE 2011) aims to cultivate individuals who are problem-solvers and critical and creative thinkers, who work effectively both as individuals and with others as members of a team. It is expected that learners should be able to organise and manage themselves and their activities responsibly and effectively, use Science and Technology effectively, show responsibility towards the environment and the health of others and demonstrate an understanding of the world as a set of related systems that are context-bound.

These ideals can be interpreted as cultivating democratic citizens who are morally sound, adaptive to change, technologically innovative and SSI literate. However, we call these postulations into question, as we have not been persuaded that these envisaged intentions are intentionally put into practice. As argued before, scholars emphasise that SSI knowledge systems should be intentionally and mindfully cultivated in the early years. In the CAPS, it is being implied that by merely teaching the content of the curriculum, the child will instinctively or incidentally be cultivated into a child citizen. The reason why we are contesting this notion is that the cultivation of citizenship is envisaged as being developed as a general (delayed) outcome (DoE 2011) and it is expected of the teacher to keep these general outcomes in mind when teaching the Life Skills subject, but the cultivation of citizenship is neither intentionally attained by a learning activity nor formally assessed.

\section{The curriculum as a collective knowledge system}

A general understanding of a curriculum is that it serves as a framework for teaching, learning and assessing a learner with regard to a specific content domain. There are two types of curriculum frameworks in South Africa. The curriculum for the early years is an integrated curriculum, and the phases beyond that utilise a collection curriculum. The characteristics of an integrated curriculum are that it consists of subject areas that are not strongly related to one another, which requires holistic teaching because the boundaries are weakly structured (Hoadley \& Jansen 2003). A collection curriculum, on the other hand, has subject areas that are closely linked, where the knowledge systems are taught as separate entities; the curriculum has boundaries to keep the content apart and is strong in structure (Hoadley \& Jansen 2003).

In the foundation phase in South African schools, one teacher is responsible for teaching the integrated curriculum, which consists of three respective subjects, namely Languages, Mathematics and Life Skills. The subject Life Skills has been organised into four study areas, namely Beginning Knowledge, Personal and Social Well-being, Creative Arts and Physical Education, in order to ensure that the foundational skills, values and concepts of early childhood development and the subjects offered in Grades 4-12 are taught and developed in Grades R to 3 (DoE 2011). The content of BK is integrated and presented as topics or themes to the young child.

Teaching BK in the early years appears not to require considerable effort, time or knowledge, as only 1-2 hours per week in a 5-week cycle are dedicated to teaching this diverse science knowledge system. The assessment of Life Skills in the early years predominantly includes informal observations, discussions, role play, demonstrations and, on occasion, written recordings (DoE 2011). The reason for this is that Life 
Skills assessment focuses on the young child's holistic development and his or her integrated understanding of concepts, skills and values, and therefore formal assessment of specific content knowledge is postponed to when learners progress to the Intermediate Phase (DoE 2011). On the other hand, in the collection curriculum of the Intermediate Phase for Grades 4-6, the BK knowledge system is now being educated as separate and isolated subjects, called Social Sciences, Natural Sciences and Technology (DoE 2011). The Intermediate Phase teacher requires approximately 7-8 hours per week to teach these subjects, which also require formal assessment. It seems that instilling a science knowledge system is primarily the responsibility of the Grade 4 teacher.

In the historicity of types of curricula having been implemented in the early years in South Africa, the provincial syllabus for Environmental Education adopted an integrated curriculum (Du Raan 1978; DvO 1991; Lea \& Gildenhuys 1967a, 1967b). The first National Curriculum Statement having been implemented in the post-apartheid era was a collection curriculum. This curriculum consisted of eight subjects, of which Social Studies, Natural Science, Technology and Economics Business Sciences were taught as respective knowledge systems to the young child (DoE 2001). The collection curriculum of the National Curriculum Statement was soon revised and replaced with an integrated curriculum. The subject Life Skills came into existence, and all science knowledge systems were merged into this subject (DoE 2003, 2011). Although it has been decreed that an integrated, fused and topic-orientated curriculum better prepares the young child for the transition to Grade 4, we are not convinced of this point. The radical shift from an integrated curriculum to a collection curriculum is challenging for young learners, as they suddenly need to rotate among teachers, they are introduced to subject-specific content and no longer themes and topics, and the didactical application changes and they are now formally assessed on what they have learnt. Not only is there a historical disconnectedness among South African curricula and syllabi, but moreover these curricula do not correlate with international frameworks for teaching, learning and assessment of science knowledge systems from kindergarten to Grade 12 (ISTE 2008; NCSS 2010; NFAS 1998; NGSS 2013; NRC 2011).

\section{The problematic nature of the Beginning Knowledge study area}

Delineating the nature of a science knowledge system (e.g. NOS) guides educators to interpret and implement an intended SSI knowledge system decorously and, furthermore, prevents them from developing misconceptions or false beliefs about what its underlying knowledge, skills and values are (Lederman et al. 2002). Therefore, demarcating the nature of BK as a study area is fundamental not only to teaching and learning an SSI knowledge system in the early years but also to cultivating democratic and active child citizens.

\section{The purpose of Beginning Knowledge}

Beginning Knowledge, as a study area, is designed to assist the child in developing an understanding of the relationship between people and the environment in order to become aware of technological processes and elementary science (DoE 2011). Through engaging with BK topics and themes the child becomes acquainted with certain concepts and skills. A probable reason for the low expectancy of the young child to acquire BK is because Life Skills is a cross-cutting subject that should support and strengthen the teaching of the other core foundation phase subjects, namely Languages and Mathematics (DoE 2011). The same notion is inferred for the provincial syllabus for Environmental Education (Du Raan 1978; DvO 1991; Lea \& Gildenhuys 1967a, 1967b), as this knowledge system was used as a context for acquiring reading, writing and arithmetic competencies. Thus, for more than 50 years, the acquisition of mere basic skills has become the essence of the young child's knowledge system.

\section{Subject matter and skills associated with Beginning Knowledge}

The name 'BK' signals the study of content and concepts that are drawn from Social Sciences (only Geography and History), Natural Sciences and Technology (DoE 2011). The CAPS utilises the collective noun 'Social Sciences', while international scholars refer to 'Social Studies'. A possible reason for this distinction is because Social Sciences indicates the study of human, societal and social relationships, while Social Studies draw on multiple fields that also influence such relations. Maxim (2014) and Seefeldt et al. (2014) include Anthropology, Sociology, Economics, Political Science and Civics, as well as globalisation, on top of Geography and History in the term 'Social Studies' that is aligned with the NCSS (2010). Crucial discussions on civics, political science and globalisation are not intentionally cultivated in BK, as it is supposed that the delayed outcomes will cultivate citizenship. The CAPS refers to the collective noun 'Natural Sciences', which restricts the science knowledge system to understanding only natural phenomena that can be observed and experimented with. The NGSS (2013), NRC (2011) and STEM or STEAM refer to science, which broadens the knowledge system to include natural and observable phenomena and also to speculate, explain, infer and make predictions about the universe.

The literature illustrates that science knowledge systems consist of concepts (knowing that) and skills (knowing how) and advocates that the latter is not inherently part of the child's consciousness or memory; rather, it should be intentionally educated simultaneously so that the child can develop a scientific vocabulary to express his or her understanding and actions (Eshach 2006; Fleer \& Pramling 2015). The key concepts for teaching Social Sciences in the early years are conservation, cause and effect, place, adaptation, relationships and interdependence, diversity and individuality as well as change (DoE 2011). Natural Sciences concepts are life and living, energy and change, matter and materials, planet Earth and beyond, and the scientific process skills include enquiry, which involves observing, comparing, classifying, measuring, experimenting and communicating (DoE 2011). Technology consists of technological process skills, such as investigation, designing, 
making, evaluating and communicating (DoE 2011). The CAPS document (DoE 2011), therefore, includes 10 Social Sciences concepts, seven Natural Sciences concepts and six skills, and five Technology skills. Interestingly, the CAPS does not include both concepts and skills for teaching Social Sciences and Technology. Furthermore, explicit mention of neither SSI nor scientific literacy is made in the entire curriculum of the BK focus (DoE 2011). When one looks at international frameworks, such as the NCSS (2010), the teaching of Social Studies includes 10 themes and 24 concepts, skills and values that accentuate citizenship. The NGSS (2013) and the NRC (2011) utilise three dimensions to cultivate Science, Technology, SSI and scientific literacy and include ample content, skills and values, presented as standards.

The problematic nature of BK has attracted our research attention, and we are of the opinion that a disconnectedness is evident in the nature and purpose of, as well as the subject matter included in, the BK study area in comparison to international knowledge systems that cultivate SSI intentionally within the early years. This detected disconnectedness inspired our endeavour to reunite culturalhistorical knowledge systems for the advancement of SSI knowledge systems in Early Childhood Education. To intellectually map the BK study area is crucial and requires a theoretical framework that can represent the complex and unique nature of this multifaceted phenomenon.

\section{Theoretical framework}

Numerous educational theories and paradigms that apply to Early Childhood Education are evident in the body of scholarship (Nutbrown \& Clough 2014); thus, selecting an appropriate framework to make sense of the phenomenon we have identified is imperative. Considering the scientifically infused dialogues on the importance of SSI education in the early years and the disconnectedness that exists within and between BK curricula and the international literature, we required a versatile theoretical framework. We realised that an intended curriculum for the early years is not a straightforward and sovereign phenomenon; rather, it is complex and influenced by various factors, both from within and from the outside. To map this knowledge system required us to do the following: to uncover its genetic origin and remain representative of Westocentric or Eurocentric and Indigenous or South African cultural-historical understandings thereof over an extended period of time; to understand how the young child acquires a science knowledge system; and to be considerate of the contribution that education, society and technology has made to its development.

Vygotsky's $(1981,1997)$ genetic law of cultural development, the cultural-historical activity theory (CHAT), the ecosystemic theory and the media theory provided the intellectual lens that we needed to address this complex phenomenon. We fused all of these into a newly coined theoretical framework, called the 'Hybrid CHAT' (Du Preez 2016).

\section{Hybrid cultural-historical activity theory (CHAT)}

The genetic law of cultural development and the CHAT originated from the groundbreaking work of Russian psychologist L.S. Vygotsky, with his cohort, Alexander Luria and Alexei Leont'ev (Sannino et al. 2009; Smidt 2009). Vygotsky took a keen interest in the work of philosopher Friedrich Hegel and sociologist Karl Marx, which influenced his thinking about context, social learning and culture (Sannino et al. 2009; Smidt 2009). Vygotsky's doctrines were only translated and made public after his death, following which various extended studies have since been conducted as third-generation cohorts, that is, Engeström, Miettinen and Punamäki (1999), Holzman (2009), Kozulin (2004), Sannino et al. (2009), Virkkunen (2009) and Wertsch and Tulviste (1992). Cultural-historical activity theory, therefore, signposts diverse factors that influence the acquisition of SSI knowledge systems for cultural development, that is, mediation and cultural tools, culture and context, language, concepts and thinking, play, and the zone of proximal development (Engeström et al. 1999; Holzman 2009; Kozulin 2004; Smidt 2009).

The general genetic law of cultural development of a knowledge system for Vygotsky $(1981,1997)$ accentuates the importance of developmental transitions as a way of understanding humans' mental functioning by means of tracing it back through the developmental changes it has undergone (Wertsch \& Tulviste 1992). Third-generation scholars have optimised Vygotsky's notion by elaborating on the importance of depicting a clear trajectory of a knowledge system by means of exploring how historical activity systems have helped shape current and potential future activity systems (Sannino et al. 2009). The mental functioning of any society about a knowledge system can, therefore, be studied through its historical trends.

How the young child acquires knowledge systems is an important focus of cultural-historical scholars. Vygotsky (1981, 1997) depicts in his scholarly writing that the internalisation of a socially instilled knowledge system by the young child ultimately transforms his or her cognisance, experience, connection and functioning. The intentional acquisition of a knowledge system transforms how the young child comes to express and ascribe meaning to his or her experience of the me-you-world because social relations genetically underlie all higher functions and behaviours (Engeström et al. 1999; Holzman 2009; Kozulin 2004; Smidt 2009; Wertsch \& Tulviste 1992). The child's meaning-making process is not directed at the environment alone but instead is mediated through cultural tools or artefacts as a collective activity with others towards a common goal (Engeström et al. 1999; Holzman 2009; Kozulin 2004; Smidt 2009; Wertsch \& Tulviste 1992). For third-generation theorists, the emphasis is on the community, collaboration, environment, and tools and signs that are shaped over time and contexts. The acquisition of a knowledge system that transforms the young child's thinking, use of language and functioning does not rely on memorising but instead on comprehension 
and using scientific language to express his or her everyday experiences that take place under the guidance of a significant other (Fleer \& Pramling 2015; Holzman 2009; Smidt 2009). Socio-scientific issues concepts, language, values and skills are, therefore, not an inherent part of the young child's consciousness, but rather such a knowledge system is culturally-historically inspired, that is, to acquire such a knowledge system requires context and an intentionaldialectical relationship through social and cultural interventions (Eshach 2006; Fleer \& Pramling 2015; Seefeldt et al. 2014; Settlage \& Southerland 2012).

The ecological systems theory and the media theory raised our awareness of the multifaceted influences that contribute to an SSI knowledge system. Urie Bronfenbrenner's (1979) ecosystemic perspective on the development of the young child indicates how different levels of interacting systems within the social context influence how a child acquires a knowledge system. The complexity of these interrelated and interactive systems (micro, exo, meso, macro and chrono) influences the knowledge systems from a social, cultural and ecological point of view (Donald, Lazarus \& Lolwana 2010). As for the media theory, this particular theory sets out how external cultural-historical changes influence knowledge systems, cultural tools and media, as well as the effect they have on the stability of activity systems (Giesecke 2005; Rückriem 2003). A cultural tool can be a physical apparatus or instrument or a medium through which semantic systems and thinking as well as worldviews are constructed and conveyed, which contributes to current knowledge systems and their future (Giesecke 2005; Rückriem 2003). Rückriem (2003) rightfully states that cultural tools are unavoidable, irreversible, general and even universal - they revolutionise the communicable structure, its interacting systems and, ultimately, the thinking and knowledge of humans. Cultural tools, as tooled knowledge, give researchers the opportunity to understand the trajectory of societal, educational and technological developments by scrutinising the functioning of the tool and how it has transferred knowledge systems throughout history.

For humans, knowledge systems do not merely exist but instead are consistently open to adaptation, expansion and transformation to progress, and they advance with current living standards and futuristic expectations (AsabereAmeyaw et al. 2012; Horsthemke et al. 2013). As humans advance, so do knowledge systems, skills, cultural tools and media as well as values. Constructing a hybridised view by merging the three theories (Hybrid CHAT) enabled us to appreciate how SSI knowledge systems and, therefore, BK as a study area have been constructed and transferred historically, along with how knowledge systems have been reconstructed and reshaped to fit the expectancies of modern life (Du Preez 2016).

\section{Research methodology}

A qualitative mode of inquiry to study a social phenomenon ordinarily serves diverse purposes, among which are exploring, describing and explaining scientific knowledge systems
(Babbie \& Mouton 1998). It also includes the historical analysis of knowledge systems (Babbie \& Mouton 1998). Historical analysis, although infrequently utilised, is a method to construct and study knowledge systems and should not be confused for a review of the literature (Babbie \& Mouton 1998; Le Roux 2013; Maree 2016). For the sake of clarity, to historically study a knowledge system requires a researcher firstly to restore the nature, fullness and complexity of the original, developed and current data, before being able to scrutinise the data, using a suitable analytical framework (Le Roux 2013; Marwick 2001). In other words, it requires meticulous research methods to reconnect knowledge systems to ignite action in addressing glitches.

To collate, customise and connect specific, and sometimes restricted, historical knowledge systems, necessitates from us to gather typographical sources from official and authorised libraries, databases, museums and archive facilities. Typographical data can be difficult to acquire owing to common errors, such as being inaccessible because the data have not been computerised, properly catalogued or are not authentic or because the text is in an unfamiliar language; consequently, interruptions or disconnectedness may be evident (Babbie \& Mouton 1998; Le Roux 2013; Maree 2016). Thus, constructing a database is an intensive, continuous, iterative and integral part of a historical research approach, seeing that the researcher needs to scan, scope, locate, select and gather historical sources systematically and purposively in an attempt to restore any interruptions, before analysing and taking on contextual and conceptual conundrums (Babbie \& Mouton 1998; Le Roux 2013; Maree 2016). It is essential to stipulate in detail how one constructs such a historical database, but because of the focus of this article, we will refer only briefly to the most prevalent aspects.

In our efforts to address the discontinuities among national curricula, syllabi and international bodies of scholarship, we collaborated closely with legitimate and authorised storage facilities, our research institution, information specialists and historical scholars to locate sources. We utilised particular search terminology, their synonyms, their historical labels and their South African and international descriptions in different combinations to locate a diverse database. Because of the enormous timeframe from the genetic origin of the data (1400-2015), the volume of documentation was vast, and it became of paramount importance to identify specific inclusion and exclusion criteria to select appropriate collections of sources, cultural tools and oral narratives that were typographically documented.

The multifaceted typographical database generated provided a rich understanding of the historical nature of the international SSI knowledge and BK study area, which we can analyse culturally-historically, using a uniquely designed analytical framework that is compatible with our Hybrid CHAT theoretical framework. The most important functions of a theoretical framework are to assist a researcher to identify and confirm gaps that exist in the body of scholarship, to provide the intellectual premises for the selection of a 
research methodology and, finally, to guide the researcher to interpret the database using a compatible analytical lens (Trafford \& Leshem 2008). Our analytical framework draws on the premise of Hybrid CHAT, Vygotsky's genetic law of cultural development and third-generation culturalhistorical theorist Engeström's (2001) approach to exploring and expanding activity systems for traces of multi-voicedness, historicity, contradictions and transformations, which enabled us to interpret the generated historical database.

\section{Analytical framework}

Knowledge systems represent an activity system where individuals actively attempt to initiate meaning-making through interactions with others and the environment and to continuously modify and create activities that trigger transformations of artefacts, tools and thinking (YamagataLynch 2007). Thus, a cultural-historical analysis of such activity systems, their psychological tools and mediated artefacts can project possible glitches and revolutions within knowledge systems (Vygotsky 1981, 1997; Wertsch \& Tulviste 1992). The analysis of cultural-historical activity systems can also assist scholars in contributing to and suggesting how the knowledge systems can be newly constructed, advanced or consolidated in order to promote the cultural development and mental functioning of societies, and the young child especially (Engeström \& Sannino 2010; Sannino et al. 2009).

According to Engeström's (2001) interpretation of CHAT, the analysis of knowledge systems can be depicted according to five principles: (1) The prime unit of analysis is interconnected to a network of other activity systems, and each activity system is artefact-mediated, collective and object-orientated and can function independently or in relation to other activity systems. The aim is to develop an understanding of action against the background of an entire activity system. (2) An activity system is multi-voiced, given its complexity and that it signifies diverse views, traditions, interests and cultural tools that are context-specific and true to a certain historical period. (3) The notion about historicity is that activity systems are shaped and transformed over long periods of time and are always context-bound. Exploring the change and development of the activity systems over time and demonstrating sensitivity towards the historical context in which the activity system is located is important. (4) Contradictions refer to the accumulation of structural tensions or disturbances that exist within and among activity systems. Activity systems are open to influences that can ignite change, innovation and development. (5) Transformation of an activity system can begin after a long cycle of changes, which then serves as the purpose or motivation of an activity system to transform. The group deliberately and collectively changes the activity system and is open to new possibilities. Box 1 presents a summary of our analytical framework and how we have applied it to explore the knowledge system of BK over a vast period of time.

The intellectual mapping of the cultural-historical development of the BK study area has been influenced by a chain of
BOX 1: The five principles to explore the historical development of the intended foundation phase Beginning Knowledge curriculum of South Africa.

\begin{tabular}{|c|c|}
\hline Five principles & Application to research inquiry \\
\hline Activity systems & $\begin{array}{l}\text { Three significant contributors in the development of BK are: } \\
\text { - educational } \\
\text { - societal } \\
\text { technological. }\end{array}$ \\
\hline $\begin{array}{l}\text { Multi- } \\
\text { voicedness }\end{array}$ & $\begin{array}{l}\text { Criteria utilised to analyse the perpendicular (vertical) } \\
\text { activity systems are: } \\
\text { - educational - subject matter knowledge and pedagogical } \\
\text { content knowledge (Ball, Thames \& Phelps 2008; } \\
\text { Shulman 1986, 1987), } \\
\text { - societal - scientific literacy for citizenship (Roberts 2007, } \\
\text { 2011) } \\
\text { - technological - educational technology and technological } \\
\text { pedagogical content knowledge (Mishra \& Koehler 2006; } \\
\text { Mishra, Koehler \& Henriksen 2011). }\end{array}$ \\
\hline Historicity & $\begin{array}{l}\text { International and South African historical contexts are } \\
\text { clustered into six epochs that stretch over approximately } \\
615 \text { years, namely: } \\
\text { - precolonial times: traditional education (1400-1652) } \\
\text { - colonial times: Dutch colonisation and education } \\
\text { (1652-1806) } \\
\text { - industrial and progressive era: British rule and education } \\
\text { (1806-1899) } \\
\text { - Child Study Movement era: missionaries, Boer } \\
\text { Republics, wars, the end of union and education } \\
\text { (1899-1948) } \\
\text { - post-World War era: National Party rule and apartheid } \\
\text { education (1948-1994) } \\
\text { - accountability and electronic era: democratic education } \\
\text { (post-1994-2017). }\end{array}$ \\
\hline Contradictions & $\begin{array}{l}\text { Criteria utilised to analyse the conglomerated (horizontal) } \\
\text { activity systems are: } \\
\text { - educational-societal: SSI for citizenship } \\
\text { - educational-technological: SSI curriculum and tools } \\
\text { technological-societal: teacher training for SSI education. }\end{array}$ \\
\hline Transformations & $\begin{array}{l}\text { The possibility of expansive transformations in activity } \\
\text { systems are: } \\
\text { - trends from the perpendicular (vertical) analysis } \\
\text { - trends from the conglomerated (horizontal) analysis. }\end{array}$ \\
\hline
\end{tabular}

Source: Adapted from Du Preez 2016; Engeström 2001:136-137

SSI, Socio-scientific issues; BK, Beginning Knowledge.

historical events in the different activity systems and will be alluded to by using the five principles developed by Engeström (2001).

\section{Activity systems}

The Hybrid CHAT theoretical framework enabled us to identify the three most significant contributors that, in our opinion, abetted in shaping SSI knowledge systems internationally and in the BK study area nationally. These activity systems are represented by 'educational', 'societal' and 'technological'. Because of the complex nature of activity systems, it cannot always be sufficiently explained, but requires one to explore it using multi-voicedness.

\section{Multi-voicedness}

The multi-voicedness of each of the three activity systems enabled us to identify underlying criteria for each perpendicular system in order to conduct a vertical analysis within each of the six epochs (see Box 1 and Figure 1). By utilising the appropriate perpendicular criteria, we could then compare the multiple historical perspectives held by both international and national bodies of scholarship about the development of SSI knowledge systems and the BK study area. The vast volume of the typographical database was constructed for each of the three respective activity systems over six epochs. To analyse the educational activity system perpendicularly we drew on the knowledge systems that an educator should include when inculcating SSI in the early years 


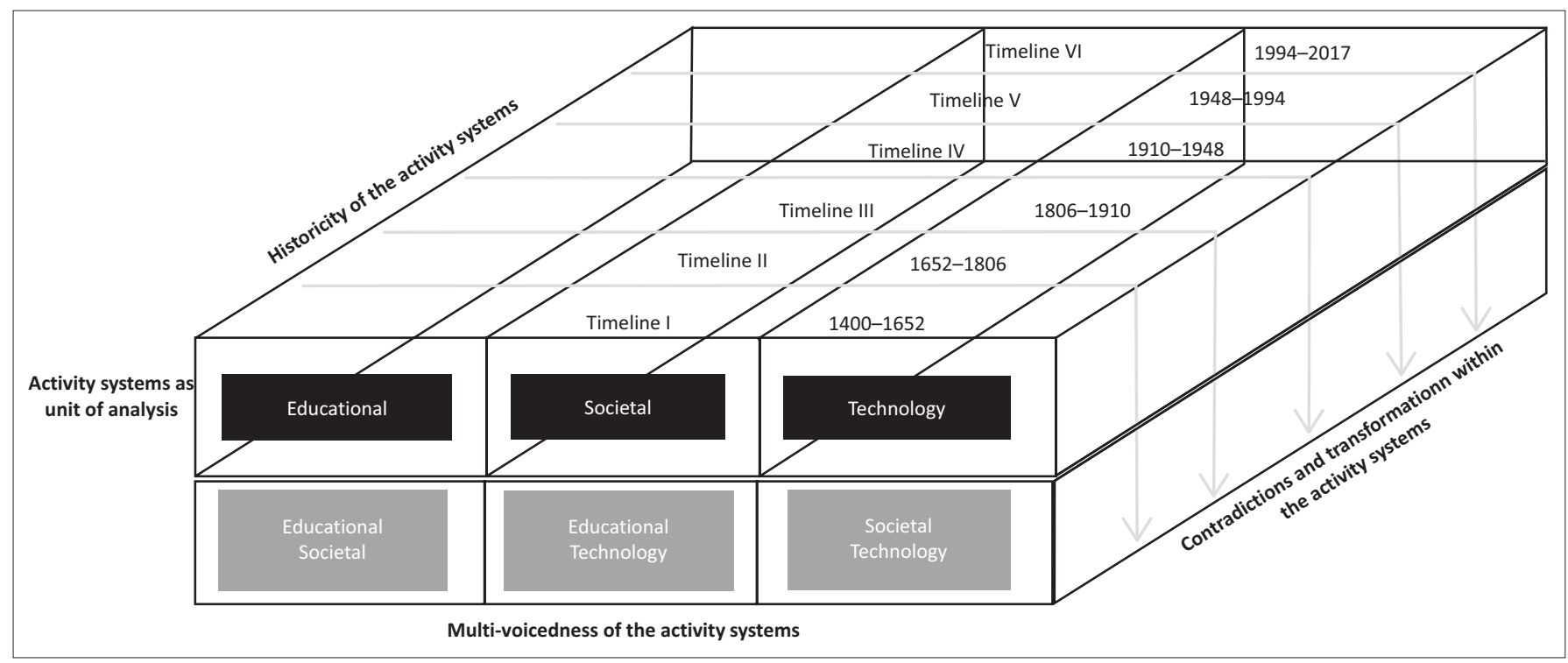

Source: Adapted from Du Preez 2016:58

FIGURE 1: Visual representation of the interrelated components of this historical research inquiry.

(Ball et al. 2008; Shulman 1986, 1987). Seven knowledge typologies were categorised as subject matter knowledge (SMK) and pedagogical content knowledge (PCK), each with their underlying typologies (Ball et al. 2008; Shulman 1986, 1987). Subject matter knowledge includes common content knowledge (CCK), horizon content knowledge (HCK) and specialised content knowledge (SCK) (Ball et al. 2008; Shulman 1986, 1987). As for pedagogical content knowledge, the three knowledge typologies that are of importance are knowledge of curriculum (KC), knowledge of content and students (KCS) and knowledge of content and teaching (KCT) (Ball et al. 2008; Shulman 1986, 1987).

For the societal activity system, we decided on scientific literacy as the major knowledge typology, with five underlying knowledge typologies (De Boer 2000; Linder et al. 2011; Roberts 2007, 2011). Scientific literacy can best account for societal requirements that contributed to the changes and progress in SSI knowledge systems through the years and according to which a teacher has a responsibility to cultivate learners for citizenship and 21st-century skills (De Boer 2000; Linder et al. 2011; Roberts 2007, 2011). Scientific literacy draws on two visions, which feeds into cultivating a knowledge society (KS). The three knowledge typologies associated with KS are language as codified knowledge, politics and economy as personal knowledge and, lastly, cultural tools as tooled knowledge. Instilling Scientific Literacy in SSI education not only advances educational, social and cultural experience but also equips the young child with the knowledge, skills and values to participate in current and future cultural-societal events (De Boer 2000; Linder et al. 2011; Roberts 2007, 2011).

We incorporated in the technological activity system educational technology and technology pedagogical content knowledge (TPACK) as our knowledge typologies for an educator (Koehler et al. 2014; Mishra \& Koehler 2006; Roblyer \& Doering 2014). The reason for this is that educational technology is not limited to only machines, physical material and software or hardware but also embraces pedagogical and didactical techniques and methods to promote SSI teaching-learning and bring about change in the young child's thinking and functioning (Giesecke 2005; Rückriem 2003). To implement educational technology in the early years requires a sound understanding of technology pedagogical content knowledge, together with knowledge of the 21st-century skills that the young child needs to acquire, in other words, knowledge of content, which includes concepts, skills and values; knowledge of pedagogy, which incorporates teaching-learning processes and practices; and knowledge of technology, which includes the classroom equipment, advanced tools and 21st-century skills akin to habits of mind (Koehler et al. 2014; Mishra \& Koehler 2006; Roblyer \& Doering 2014). Understanding the multi-voicedness of each activity system is imperative for a conceptual understanding; however, historicity is required for a contextual understanding.

\section{Historicity}

To explore the development of the SSI knowledge system and BK as a study area through its genetic origin we drew on the historicity principle. Looking at the rich historical account of national and international occurrences enabled us to inaugurate a timeline or epoch, consisting of six national educational periods (Booyse et al. 2013), which we merged with the six most significant international societal and technological transitions (Dever \& Falconer 2008; Luke 1989; McLuhan 1962). The synthesised and synchronised time epochs (see Table 1 and Figure 1) that we utilised in our historical research inquiry are as follows: (1) precolonial times: traditional education (1400-1652); (2) colonial times: Dutch colonisation and education (1652-1806); (3) industrial and progressive era: British rule and education (1806-1899); (4) Child Study Movement era: missionaries, Boer Republics, wars, the end of union and education (1899-1948); (5) postWorld War era: National Party rule and apartheid education (1948-1994); and the accountability and electronic era: 
democratic education (post-1994-2017). Seeing that activity systems do not function in isolation at a specific moment in time, it is also important to explore the interaction, tensions and contradictions that can occur when perpendicular systems are conglomerated.

\section{Contradictions}

As argued earlier, the fact that some curricula and syllabi, together with the body of scholarship, for decades postulated the assumption that the young child should only be educated to become literate on basic skills of reading, writing and arithmetic clearly conveys the possibility that knowledge systems can become stagnant and reluctant to advance. In order to detect openness for change in an activity system we created horizontal tensions (see Table 1 and Figure 1), called 'contradictions', between the activity systems over a historical period by conglomerating the three activity systems into the (1) educational-societal, (2) educational-technological and (3) technological-societal systems. These conglomerated activity systems enabled us to develop an understanding about the activity that occurred among them and how this contributes to shaping or stagnating SSI knowledge systems across six epochs. Change and expansion are inevitable as no activity system can remain stagnant incessantly; thus, investigating the possibilities for transformation is crucial.

\section{Transformations}

Activity systems can undergo transformation when the purpose of and motivation for the activity have been reconceptualised by the members and they want to embrace the possibility for change and move away from the former mode of the activity (Engeström 2001). By applying the proposed theoretical and analytical frameworks, we could explore the constructed SSI knowledge system over an extended historical period to substantiate or detect connectedness or anomalies in the knowledge systems, internationally and nationally (Du Preez 2016). Furthermore, we could ascertain whether the activity systems were open to transformation or, to the contrary, what was inhibiting the activity system from progressing (Du Preez 2016). The possibility that expansive transformations in activity systems could lead to changes necessitates the identification of predominant trends from both the perpendicular (vertical) analysis and the conglomerated (horizontal) analysis (Du Preez 2016).

\section{Conclusion}

Unquestionably, the world of the young child has advanced technologically and scientifically and has initiated societies to become significantly connected, seeing that every decision that is made has the potential for global impact (Ratcliff \& Grace 2003; Zeidler \& Kahn 2014). The 21st-century child will need to appreciate SSI to be able to conduct research, scrutinise information, demonstrate thoughtful reflection and understand the moral and ethical implications of his or her decisions within the world (Asabere-Ameyaw et al. 2012; Mishra et al. 2011; Sadler 2011; Zeidler \& Kahn 2014). Consequently, the ability to acquire and master such an SSI knowledge system can be a daunting task for the young child and more reason to infuse citizenship and scientific literacy in the early years under the guidance of mindful and knowledgeable educators (Asabere-Ameyaw et al. 2012; Fleer \& Pramling 2015; Sadler 2011; Zeidler \& Kahn 2014). Seeing that past knowledge systems influence the trajectory and progress of future knowledge systems, we can deduce that they are historically integrated and connected. Determining whether the SSI knowledge system for the young child is attaining its purpose calls for a research inquiry that maps the historicity thereof to reconstitute traces left behind by past societies and replenish any silences that may exist.

A study of this nature and magnitude requires a complex and well-conceptualised theoretical and analytical framework, together with a suitable research methodology. The newly coined theoretical framework, Hybrid CHAT, together with its compatible analytical framework, enabled us to construct a rigorous, iterative (non-linear) typographical database that can commence in mapping the historicity of SSI knowledge systems and the BK study area for the young child in South Africa. In summary, the theoretical-analytical framework can advocate the type of transformation that is required of activity systems to promote and restore a knowledge system because of its finding in historicity, multi-voicedness and manifesting contradictions (Engeström \& Sannino 2010; Sannino et al. 2009). What sets this theoretical-analytical framework apart from other inquiries is its transformative, expansive and genetic nature. It is suggested that a communal aspiration be developed among scholars and curriculum developers to reconnect, transform and advance SSI education in the early years. It is crucial to prepare today's children to be tomorrow's informed citizens, who are set for the future but are still firmly grounded in their historical roots.

\section{Acknowledgements}

This article is based on the PhD dissertation of H. du Preez, entitled 'A historical subject-didactical genetic analysis of Life Skills education in early childhood', under the supervision of Dr H.M. van Niekerk, North-West University, Potchefstroom.

\section{Competing interests}

The authors declare that they have no financial or personal relationships that may have inappropriately influenced them in writing this article.

\section{Authors' contributions}

H.d.P. is the lead author and responsible for conducting the entire research inquiry. H.d.P. and R.v.N. collaborated in conceptualising and designing the research inquiry. H.d.P. 
continuously scanned, scoped, gathered and selected most suitable textual sources for analysis and interpretation in a systematic and purposive manner. H.d.P. and R.v.N. cooperated in constructing the newly coined theoretical framework and its aligned analytical framework to map the historicity of the field of knowledge. R.v.N. is the co-author and supervisor of this article and was responsible for critical reading of all content, synthesis and analysis reflected in the manuscript.

\section{References}

Abd-El-Khalick, F., Bell, R.L. \& Lederman, N.G., 1998, 'The nature of science and instructional practice: Making the unnatural natural', Science Education 82(4), 417-436. https://doi.org/10.1002/(SICI)1098-237X(199807)82:4<417::AID-SCE1> 3.0.CO;2-E

Asabere-Ameyaw, A., Sefa Dei, G.J. \& Raheem, K., 2012, Contemporary issues in African sciences and science education, Sense Publishers, Rotterdam.

Babbie, E. \& Mouton, J., 1998, The practice of social research, Oxford University Press, Cape Town.

Ball, D.L., Thames, M.H. \& Phelps, G., 2008, 'Content knowledge for teaching. What makes it special?', Journal of Teacher Education 59(5), 389-407. https://doi.org/ 10.1177/0022487108324554

Booyse, J.J., Le Roux, C.S., Seroto, J. \& Wolhuter, C.C. (eds.), 2013, A history of schooling in South Africa, Van Schaik, Pretoria.

Bronfenbrenner, U., 1979, The ecology of human development, Cambridge University Press, Harvard.

Bybee, R.W., 2010, The teaching of Science: 21st-century perspectives, NSTA, Arlington, TX.

Chaillé, C. \& Britain, L., 2003, The young child as scientist: A constructivist approach to early childhood science education, 3rd edn., Pearson, Boston, MA.

Dever, M.T. \& Falconer, R.C., 2008, Foundations and change in early childhood education, John Wiley, Hoboken, NJ.

Department of Education, 2002, C2005 Revised National Curriculum Statement (RNCS), Grade R-3 (Schools), Foundation Phase, Government Printers, Pretoria.

Department of Education, 2003, Revised National Curriculum Statement (RNCS), Grade R-3 (Schools), Life Skills, Government Printers, Pretoria.

Department of Education, 2011, Curriculum and Assessment Policy Statement. (CAPS). Grade R-3, Life Skills, Government Printers, Pretoria.

Departement van Onderwys, 1991, Riglyne vir onderwysers met betrekking tot die aanbieding van omgewingsleer in die Junior Primêre fase (Graad 1 en 2 en Standerd 1), Staatsdrukker, Pretoria.

De Boer, G.E., 2000, 'Scientific literacy: Another look at its historical and contemporary meanings and its relationship to science education reform', Journal of Research in Science Teaching 37(6), 582-601.

Du Preez, H., 2016, 'A historical subject-didactical genetic analysis of life skills education in early childhood', PhD thesis, North-West University, Potchefstroom

Du Raan, A., 1978, Handleiding vir omgewingsleer. Sub A en B, en Standard 1 Voortrekkerpers, Johannesburg.

Donald, D., Lazarus, S. \& Lolwana, P., 2010, Educational psychology in social context. Ecosystemic applications in South Africa, 4th edn., Oxford University Press, Cape Town

Engeström, Y., Miettinen, R. \& Punamäki, R.L. (eds.), 1999, Perspectives on activity theory, Cambridge University Press, Cambridge.

Engeström, Y., 2001, 'Expansive learning at work: Toward an activity theoretical reconceptualization', Journal of Education and Work 14(1), 133-156. https://doi. reconceptualization', Journal of Ed
org/10.1080/13639080020028747

Engeström, Y. \& Sannino, A., 2010, 'Studies of expansive learning: Foundations, findings and future challenges', Educational Research Review 5, 1-24. https://doi. org/10.1016/j.edurev.2009.12.002

Erduran, S. \& Dagher, Z.R., 2015, Reconceptualizing the nature of science for Science education, Springer, New York, NY.

Eshach, H., 2006, Science literacy in primary schools and pre-schools, Springer, Rotterdam.

Giesecke, M., 2005, In search of post-typographical educational ideals, Suhrkamp Frankfurt.

Fleer, M. \& Pramling, N., 2015, A cultural-historical study of children learning science. Foregrounding affective imagination in play-based settings, vol. 11, Springer, New York, NY.

Glauert, E. \& Manches, A., 2012, Creative little scientists: Enabling creativity through science and mathematics in preschool and first years of primary education Institute of Education, University of London.

Hoadley, U. \& Jansen, J., 2003, Curriculum. From plans to practices, Oxford University Press, Johannesburg.
Hodson, D., 2009, Teaching and learning about Science: Language, theories, methods, history, traditions and values, Sense Publishers, Rotterdam.

Horsthemke, K., Siyakwazi, P., Walton, E. \& Wolhuter, C.C. (eds.), 2013, Education studies. History, Sociology, Philosophy, Oxford University Press, Cape Town.

Holzman, L., 2009, Vygotsky at work and play, Routledge, New York, NY.

International Society for Technology in Education, 2008, National educational technology standards for teachers, 2 nd edn., Author, Eugene, OR.

Kaku, M., 1997, Visions: How science will revolutionize the 21st century, First Anchor Books, New York, NY

Kaku, M., 2011, Physics of the future: How science will shape human destiny and our daily lives by the year 2100, Doubleday Publishers, New York, NY.

Koehler, M.J., Mishra, P., Kereluik, K., Shin, T.S. \& Graham, C.R., 2014, 'The technological pedagogical content knowledge framework', in J.M. Spector, M.D. Merrill, J. Elen \& M.J. Bishop (eds.), Handbook of research on Educational Communications and Technology, 4th edn., pp. 101-111, Springer, New York, NY.

Kozulin, A., 2004, 'Vygotsky's theory in the classroom: Introduction', European Journal of Psychology of Education 19(1), 3-7. https://doi.org/10.1007/BF03173233

Lea, E. \& Gildenhuys, A.M.J., 1967a, Omgewingsleer - Graad I. Handleiding vir onderwysers, Voortrekkerpers, Johannesburg.

Lea, E. \& Gildenhuys, A.M.J., 1967b, Omgewingsleer - Graad II. Handleiding vir onderwysers, Voortrekkerpers, Johannesburg.

Le Roux, C.S., 2013, 'History of education research: A search for meaning', in K. Horsthemke, P. Siyakwazi, E. Walton \& C.C. Wolhuter (eds.), A history of schooling in South Africa, pp. 17-36, Oxford University Press, Johannesburg.

Lederman, N.G., Abd-El-Khalick, F., Bell, R.L. \& Schwartz, R.S., 2002, 'Views of nature of science questionnaire: Toward valid and meaningful assessment of learners' conceptions of nature of science', Journal of Research in Science Teaching 39(6) 497-521. https://doi.org/10.1002/tea.10034

Linder, C., Ostman, L., Roberts, D.A., Wickman, P., Erickson, G. \& MacKinnon, A. (eds.), 2011, Exploring the landscape of scientific literacy, Routledge, New York, NY.

Maree, K. (ed.), 2016, First steps in research, 2nd edn., Van Schaik, Pretoria.

Maxim, G.W., 2014, Dynamic social studies for constructivist classrooms: Inspiring tomorrow's social scientists, 10th edn., Pearson, Upper Saddle River, NJ.

Luke, C., 1989, Pedagogy, printing, and Protestantism: The discourse on childhood, State University Press, New York, NY.

Marwick, A., 2001, The new nature of history - Knowledge, evidence, language, Palgrave, Basingstoke.

McLuhan, M., 1962, The Gutenberg galaxy: The making of typographic man, University of Toronto Press, Toronto.

Mishra, P. \& Koehler, M.J., 2006, 'Technological pedagogical content knowledge: A framework for teacher knowledge', Teachers College Record 108(6), 1017-1504. https://doi.org/10.1111/j.1467-9620.2006.00684.x

Mishra, P., Koehler, M.J. \& Henriksen, D., 2011, 'The seven trans-disciplinary habits of mind: Extending the TPACK framework towards 21st century learning', Educational Technology 51(2), April-May, 22-27.

National Association for the Education of the Young (NAEYC) \& National Association of Early Childhood Specialists in State Departments of Education (NAECS/SDE), 2002, Early learning standards: Creating the conditions for success. Joint position statement, Author, Washington, DC.

National Council for Social Studies, 2010, National curriculum standards for social studies, Author, Silver Spring, MD.

National Research Council, 2011, Successful K-12 STEM education: Identifying effective approaches, National Academic Press, Washington, DC

Next Generation Science Standards, 2013, Next generation science standards: For states, by states, National Academies Press, Washington, DC.

Nuffield Foundation and the Association for Science Education, 1998, Beyond 2000 Science education for the future, King's College, London.

Nutbrown, C. \& Clough, P., 2014, Early childhood education. History, philosophy and experience, 2nd edn., Sage, New York, NY.

Parker, W., 2009, Social studies in elementary education, 14th edn., Pearson, Chennai.

Pinar, W.F. (ed.), 2010, 'Introduction', in W.F. Pinar (ed.), Curriculum studies in South Africa: Intellectual histories \& present circumstances, pp. 1-19, Palgrave, New York, NY.

Ratcliffe, M. \& Grace, M., 2003, Science education for citizenship. Teaching socioscientific issues, Open University Press, Philadelphia, PA.

Roberts, D.A., 2007, 'Scientific literacy/science literacy', in S.K. Abell \& N.G. Lederman (eds.), Handbook of research on science education, pp. 729-780, Lawrence Erlbaum, NJ.

Roberts, D.A., 2011, 'Competing visions of scientific literacy: The influence of sciences curriculum policy image', in C. Linder, L. Ostman, D.A. Roberts, P. Wickman, G. Erickson \& A. Mackinnon (eds.), Exploring the landscape of scientific literacy, pp. 11-27, Routledge, New York, NY.

Roblyer, M.D. \& Doering, A.H., 2014, Integrating educational technology into teaching, 6th edn., Pearson, Harlow.

Rückriem, G., 2003, Tool or medium? The meaning of information and telecommunication technology to human practice. A quest for systemic understanding of activity theory Center for Activity Theory and Developmental Work Research, Helsinki.

Sadler, T.D., 2011, 'Socio-scientific issues-based education: What we know about science education in the context of SSI', in T.D. Sadler (ed.), Socio-scientific issues in the classroom, pp. 355-369, Springer, Netherlands. 
Sadler, T.D., Barab, S.A. \& Scott, B., 2006, 'What do students gain by engaging in socioscientific inquiry?', Research in Science Education 37(4), 371-391. https://doi. org/10.1007/s11165-006-9030-9

Sannino, A., Daniels, H. \& Gutiérrez, K.D. (eds.), 2009, 'Activity theory between historical engagement and future-making practice', in A. Sannino, H. Daniels \& K.D. Gutiérrez (eds.), Learning and expanding with activity theory, pp. 1-19, University Press, Cambridge.

Seefeldt, C., Castle, C. \& Falconer, R.C., 2014, Social studies for the preschool/primary child, 9th edn., Pearson, Boston, MA

Settlage, J. \& Southerland, A., 2012, Teaching science to every child using culture as a starting point, 2nd edn., Routledge, New York, NY.

Siu, K.W.M. \& Lam, M.S., 2005, 'Early childhood technology education: A sociocultura perspective', Early Childhood Education Journal 32(6), 353-358. https://doi.org/ 10.1007/s10643-005-0003-9

Soudien, C., 2010, 'What to teach the natives: A historiography of the curriculum dilemma in South Africa', in W.F. Pinar (ed.), Curriculum studies in South Africa: Intellectual histories \& present circumstances, pp. 19-50, Palgrave, New York, NY.

Shulman, L.S., 1986, 'Those who understand: Knowledge growth in teaching', Educational Researcher 15(2), 4-14. https://doi.org/10.3102/0013189X015002004

Shulman, L.S., 1987, 'Knowledge and teaching: Foundations of the new reform', Harvard Educational Review 57(1), 1-22. https://doi.org/10.17763/haer.57.1. j463w79r56455411
Smidt, S., 2009, Introducing Vygotsky. A guide for practitioners and students in early years education, Routledge, New York, NY.

Trafford, V. \& Leshem, S., 2008, Stepping stones to achieving your doctorate by focusing on your viva from the start, Open University Press, Berkshire.

Virkkunen, J., 2009, 'Two theories of organizational knowledge creation', in A. Sannino, H. Daniels \& K.D. Gutiérrez (eds.), Learning and expanding with activity theory, pp. 144-159, Cambridge University Press, Cambridge.

Vygotsky, L.S., 1981, 'The genesis of higher mental functions', in J.V. Wertsch (ed.), The concept of activity in Soviet psychology, pp. 144-188, Sharpe, Armonk.

Vygotsky, L.S., 1997, The collected works of L.S. Vygotsky: The history of the development of higher mental functions, vol. 4, Plenum, New York, NY.

Wertsch, J.V. \& Tulviste, P., 1992, 'L.S. Vygotsky and contemporary developmental psychology', Developmental Psychology 28(4), 548-557. https://doi.org/10.1037/ 0012-1649.28.4.548

Yamagata-Lynch, L.C., 2007, 'Confronting analytical dilemmas for understanding complex human interactions in design-based research from a cultural-historical activity theory (CHAT) framework', The Journal of the Learning Sciences 16(4), 451-484. https://doi.org/10.1080/10508400701524777

Zeidler, D.L. \& Kahn, S., 2014, It's debatable!: Using socio-scientific issues to develop scientific literacy, K-12, NSTA, Arlington, TX. 